\title{
Pembinaan dan Pengembangan Kompetensi Generik Calon Guru bagi Meningkatnya Daya Saing Berbasis Multiple Intelligences Theory (MIT)
}

\author{
Nelly Yusra, Rian Vebrianto
}

Universitas Islam Negeri Sultan Syarif Kasim Riau, Indonesia

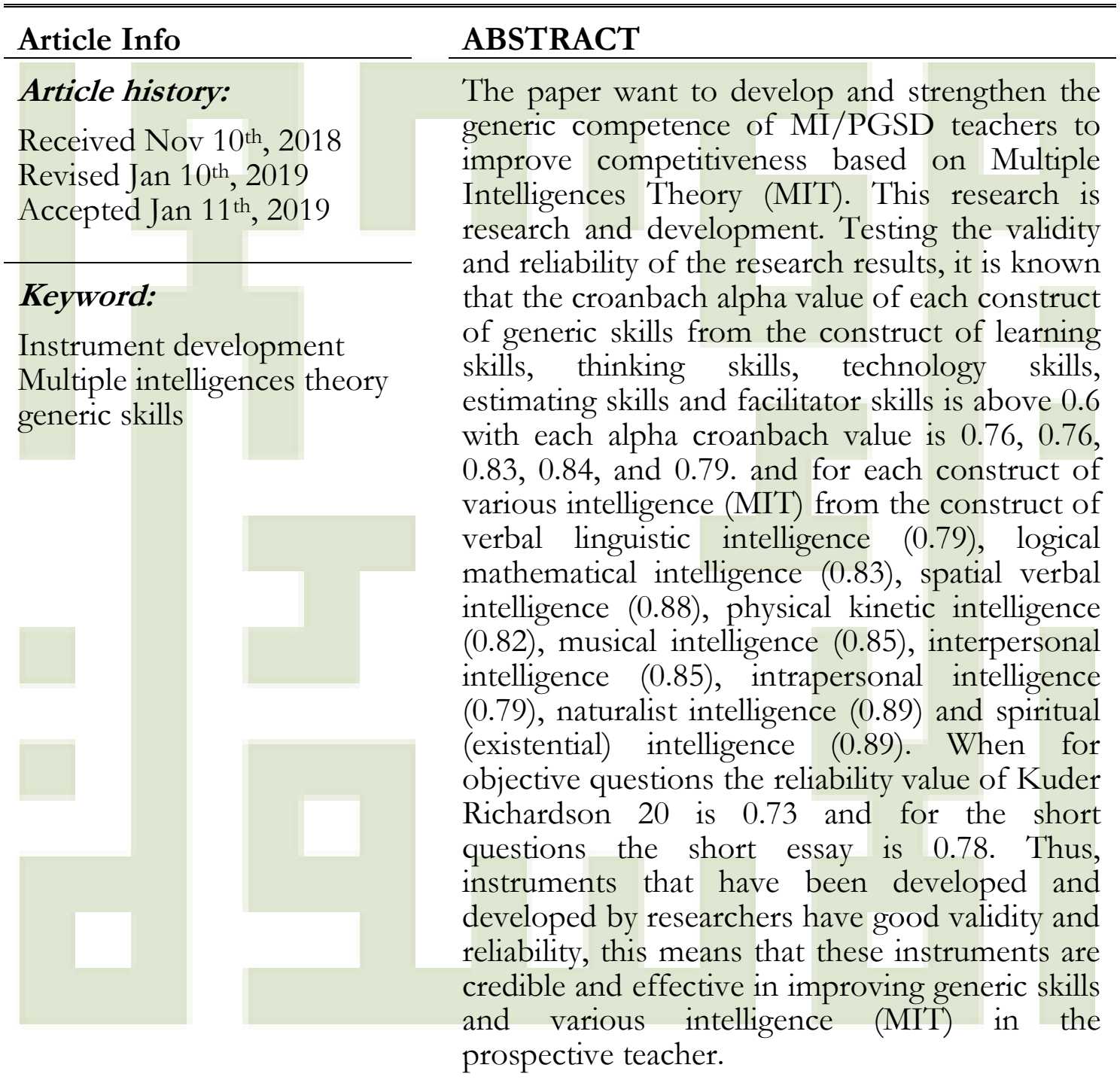

Corresponding Author:

\section{Nelly Yusra}

Universitas Islam Negeri Sultan Syarif Kasim Riau, Indonesia

Email: nellyyusra1@gmail.com 


\section{PENDAHULUAN}

Visi umum pendidikan tinggi adalah melahirkan orang-orang terdidik (educated people) insan yang berkarakter, cerdas dan terampil untuk membangun bangsa Indonesia yang bermartabat dan berdaya saing tinggi, memiliki kemampuan komprehensif utuh, menciptakan kemakmuran, keamanan, kesejahteraan dan keadilan. Misi ini dapat dicapai jika kurikulum pendidikan tinggi yang dikembangkan efektif untuk memenuhi keperluan mahasiswa, mengembangkan nilai-nilai, IPTEKS, keterampilan, sikap mental dan etika menjadi warga negara sekaligus warga dunia yang bertanggung jawab, dan berkontribusi dalam membangun keadaban, kemanfaatan, dan kebahagiaan bagi bangsa khususnya dan kemanusian umumnya. ${ }^{1}$

Tema ini, sejalan dengan Visi dan Misi UIN Suska Riau 2023 serta isu strategis yang sedang berkembang di UIN Suska Riau, yaitu "integrasi keilmuan dan keislaman" (mengintegrasi sains dan teknologi serta seni dengan nilai-nilai keIslaman menuju world class university).

Peraturan Pemerintah Republik Indonesia Nomor 19 Tahun 2005 tentang Standar Nasional Pendidikan dan Nomor 32 Tahun 2013 tentang Perubahan Standar Nasional Pendidikan pasal 1 ayat 8 , secara eksplisit menegaskan bahwa pendidik dan tenaga kependidkan harus

${ }^{1}$ Evi Suryawati, "Pengembangan Model Peningkatan Kompetensi dan Daya Saing Lulusan MIPA LPTK Berbasis KKNI dan Kerangka TPCK," Stranas, 2015, 67-68. memenuhi kriteria dan kelayakan pendidikan pra jabatan dan jabatan. Guru adalah pendidik profesional dengan tugas utama mendidik, mengajar, membimbing, mengarahkan, melatih, menilai, dan mengevaluasi peserta didik pada pendidikan anak usia dini jalur pendidikan formal, pendidikan dasar, dan pendidikan menengah. Guru yang profesional akan menghasilkan proses dan hasil pendidikan yang bermutu dalam rangka mewujudkan insan Indonesia yang cerdas dan kompetitif, yaitu manusia yang beriman dan bertakwa kepada Tuhan Yang Maha Esa, berakhlak mulia, sehat, berilmu, cakap, kreatif, mandiri, serta menjadi warga negara yang demokratis dan bertanggung jawab. Untuk menjadi guru yang profesional, maka diharuskan memiliki kemampuan dalam mengembangkan aspek kompetensi yang ada pada dirinya.

Berdasarkan Undang-Undang Republik Indonesia Nomor 14 Tahun 2005 tentang Guru dan Dosen, kompetensi guru tersebut meliputi kompetensi pedagogik, kompetensi profesional, kompetensi sosial, dan kompetensi kepribadian. Salah satu kompetensi pedagogik yang penting adalah kompetensi keterampilan generik. $^{2}$

Teknologi informasi yang berkembang saat ini telah dimanfaatkan oleh seluruh umat di dunia. Kemajuan teknologi yang ada, telah

2Ibid. 
mengubah perilaku sebagian atau bahkan semua gaya hidup manusia saat ini. ${ }^{3}$ Mengikut John Naisbitt dalam NCREL (2004), suatu bangsa atau negara yang unggul dalam tekhnologi informasi, maka bangsa atau negara tersebut akan unggul pula dalam mendominasi dunia. Untuk mengantisipasi kecenderungan perkembangan dunia yang semakin maju saat ini pemerintah Indonesia melalui Departemen Pendidikan Nasional telah menggubal dan mempersiapkan para guru agar mampu lebih bersaing dalam penguasaan Information and Communication Technology (ICT) dalam menjalankan amanah sebagai guru yang profesional sehingga proses pembelajaran menjadi efektif dan efisien. Proses penguasaan teknologi menjadi perkara yang sangat penting bagi guru dalam menerokai dan menambah wawasan dan informasi yang diperlukan. ${ }^{4}$

Selain kemampuan terhadap penggunaan tekhnologi informasi guru harus faham bahwa kecerdasan siswa itu beranekaragam. Pada awal 1980-an, psikolog Howard Gardner memperkenalkan suatu teori kognitif baru yang dinamakannya Multiple

3J. Herrington, et. al., "Design-based research and doctoral students: Guidelines for preparing adissertation proposal," in C. Montgomerie \& J. Seale (Eds.), Proceedings of World Conference on Educational Multimedia, Hypermedia and Telecommunications (2007): 40894097.

${ }^{4} \mathrm{R}$. Vebrianto, \& K. Osman, "The effect of multiple media instruction in improving students' science process skill and achievement. sciencedirect," Procedia Social and Behavioral Sciences 15 (2011): 346-350.
Intelligences Theory (MIT), sebagai sebuah alternatif terhadap pendekatan lama yang menekankan hanya kecerdasan logis matematis. Multiple Intelligences Theory (MIT) dikenal juga dengan nama teori kecerdasan berbagai, teori kecerdasan majemuk, teori kecerdasan jamak. Teori ini mempertahankan suatu pandangan yang pluralistik mengenai pikiran, mengakui banyak aspek kognisi yang berlainan yang memiliki kekhasan masing-masing dan memandang setiap individu memiliki kekuatan-kekuatan kognitif yang berbeda dan gaya kognitif yang tidak sama. Model MIT dilandaskan terutama pada temuan-temuan mutakhir sains kognitif (yang mempelajari pikiran) dan neurosains (yang mempelajari otak). ${ }^{5}$ Dalam pandangan Gardner, menetapkan peringkat kecerdasan seseorang hanya berdasarkan tes IQ (yakni tes atas kemampuan nalar logis matematis, bersama dengan kemampuan linguistik), berarti mengabaikan kemampuan-kemampuan kognitif lain yang ada dalam diri setiap manusia, yang tidak kalah signifikansinya jika di-bandingkan dengan kecerdasan logis matematis. Sementara tetap menghargai instrumen psikometrik tes $I Q$, dia menyatakan dengan tegas bahwa instrumen ini sama sekali tidak adil. ${ }^{6}$

Pendidikan merupakan kunci untuk semua kemajuan dan per-

${ }^{5}$ Howard Gardner, Multiple Intelligences: The Theory in Practice (New York: Basic Books, 1993), 35.

IIbid., 41. 
kembangan yang berkualitas dalam sebuah negara karena dengan pendidikan, manusia dapat mewujudkan semua potensi yang ada pada dirinya baik sebagai peribadi maupun sebagai warga masyarakat. ${ }^{7}$

Dalam upaya benchmarking internasional, merujuk pada tiga studi utama sebagai instrumen untuk menguji kompetensi global saat ini, yaitu Progress in International Reading Literacy Study (PIRLS), Third International Mathematics and Science Study (TIMSS), dan Program of International Student Assesment (PIS A). ${ }^{8}$

Studi tahun 2006 menunjukkan literasi membaca siswa Indonesia adalah 407, hal ini bererti bahwa siswa Indonesia termasuk negara yang memiliki pencapaian literasi membacanya dibawah purata negara peserta PIRLS 2006 yaitu 500, di mana posisi literasi membaca pelajar Indonesia berada pada posisi kelima dari urutan terbawah negara-negara peserta PIRLS 2006. Selanjutnya hasil yang telah dijalankan oleh PIS A menunjukkan dari 42 negara yang disurvei, psiswa Indonesia menduduki peringkat ke-39 dengan purata nilai 371. Literasi membaca ini meliputi kemahiran menemukan maklumat, memahami dan menafsirkan bacaan, serta melakukan

7O.S. Tan, Problem-Based Learning Innovation: Using Problem to Power Learning in the 21st Century (Singapore: GALE Cengage Learning, 2004), 132.

${ }^{8}$ Bahrul Hidayat \& Suhendra Yusuf, Benchmark Internasional Mutu Pendidikan (Jakarta: Bumi Aksara, 2010), 65. refleksi dan penilaian terhadap apa yang dibaca. ${ }^{9}$

Selanjutnya, pencapaian siswa dalam literasi sains pada PISA 2006, dari 57 negara peserta, siswa Indonesia berada pada posisi ke 50 dengan purata nilai 393, manakala pada studi sebelumnya PISA 2003 purata nilai 395. Ini berarti pada literasi sains siswa Indonesia mengalami penurunan pencapaian sebanyak 2 poin. Kemudian, penelitian yang dijalankan oleh TIMSS pada tahun 2007 siswa Indonesia menduduki posisi ke 35 dari 47 negara peserta TIMSS. ${ }^{10}$

Guru merupakan salah satu faktor yang penting dalam menyediakan proses pembelajaran yang baik dan inovatif. Dengan adanya data yang mencengangkan ini, maka tanggung jawab seorang guru semakin besar dan harus segera ditindaklanjuti dengan memberikan pemahaman dan pemupukan terhadap berbagai keterampilan yang harus di miliki oleh guru. Untuk itu, maka peneliti, ingin melakukan pengembangan dan penguatan kompetensi generik calon guru MI bagi meningkatkan daya saing berbasis Multiple Intelligences Theory (MIT).

9Ibid., 67.

${ }^{10} \mathrm{P}$. Gonzales, T. Williams, L. Jocelyn, S. Roey, D. Kastberg, and S. Brenwald, Highlights From TIMSS 2007: Mathematics and Science Achievement of U.S. Fourth- and EighthGrade Students in an International Context (NCES 2009-001). (Washington DC.: National Center for Education Statistics, Institute of Educationn Sciences, U.S. Department of Education, 2008), 89. 
Penelitian pengembangan model peningkatan kompetensi keterampilan generik dan daya saing lulusan FTK MI SUSKA RIAU berbasis Multiple Intelligences Theory (MIT) yang akan dilaksanakan bertujuan untuk mengembangkan model peningkatan kompetensi keterampilan generik dan daya saing lulusan FTK MI UIN SUSKA RIAU yang berkualitas untuk memenuhi kebutuhan profesional, sosial, dan industri.

Secara khusus tujuan yang ingin dicapai melalui penelitian pengembangan skim strategi nasional, yaitu (1) merancang dan mengembangkan model peningkatan kompetensi generik lulusan FTK berbasis Multiple Intelligences Theory (MIT); (2) menghasilkan instrumen pembelajaran model peningkatan kompetensi berbasis Multiple Intelligences Theory (MIT).

\section{LANDASAN TEORI}

Keterampilan generik adalah keterampilan yang dominan dalam proses belajar mengajar, dalam penelitian ini, ada lima keterampilan generik dalam proses belajar mengajar yang harus dimiliki dan dikuasai oleh guru dan siswa yaitu: keterampilan belajar, keterampilan berfikir, keterampilan tekhnologi, keterampilan menaksir/menilai, dan keterampilan fasilitator.

$$
\text { Menurut Gardner dan }
$$

Armstrong, terdapat sembilan jenis kecerdasan dalam MIT, yaitu: (1) kecerdasan verbal-linguistik, kecerdasan matematika-logis, (3) kecerdasan visual-spasial, (4) kecerdasan kinestetik-jasmani, (5) kecerdasan musikal, (6) kecerdasan interpersonal, (7) kecerdasan intrapersonal dan (8) kecerdasan naturalis (9) kecerdasan eksistensial/ kerohanian. ${ }^{11}$

Dalam proses pembelajaran di sekolah kadang guru lupa akan adanya keberbagaian kecerdasan pada diri siswa, sehingga guru kurang dapat mengalai akan adanya potensi atau talent yang terpendam pada diri siswa tersebut. Selain itu faktor kompetensi pedagogi dalam hal ini keterampilan generik merupakan keterampilan yang patut ada pada diri guru guna dapat mefasilitasi dan mengarahkan siswa agar dapat melaksankan proses pengajaran dan pembelajaran dengan efektif dan efisien serta inovatif. Keterampilan generik dan teori kecerdasan yang dikenal dengan Multiple Intelligences Theory (MIT) akan memberikan keluluasan berfikir dan bernalar untuk memaksimalkan sebuah hasil (produk) dalam bingkai tujuan pembelajaran yang diharapkan.

Penerapan MIT di sekolah akan: (1) menghasilkan guru yang mempunyai tanggungjawab dan akuntabilitas sepenuhnya dalam proses dan isi dalam belajar mengajar; (2) meningkatkan kualitas guru yang bukan hanya sekedar menyebarkan pengetahuan dan

${ }^{11}$ Howard Gardner, Multiple Intelligences...; T. Armstrong, Multiple intelligences in the classroom (3nd ed.). Alexandria, VA: ASCD., 2009), 193. 
informasi tetapi memupuk semangat baru; (3) mengalakkan inovasi dan penelitian baru dalam proses belajar mengajar. Dari sisi sistem penilaian pula diketahui penerapan MIT akan memberikan keutamaan di antaranya: (1) penilaian lebih bersifat adil karena mempertimbangkan sembilan kecerdasan dan tidak hanya tertumpu pada satu kecerdasan saja; (2) pelajar mendapat peluang untuk menunjukkan kefahaman mereka tentang sesuatu isi teori atau keterampilan dalam berbagai cara dan metode; (3) melalui penilaian guru mengetahui kekuatan dan kelemahan pelajar dan itu akan dapat merancang proses belajar mengajar yang lebih berkesan dan efektif. ${ }^{12}$

Manakala di sekolah, MIT mewujudkan sekolah yang menerima dan menghargai perbedaan kecerdasan di kalangan pelajar dan juga guru. Di sini guru akan merancang secara kolaboratif dengan mengggunakan kerangka MIT untuk menyediakan kurikulum yang diperkayakan dan penuh dengan rangsangan serta motivasi, menghargai sumbangan yang berbeda dari setiap orang dari segi perancangan, organisasi dan pelaksanaan kurikulum serta mengambil tanggung jawab keatas pembelajaran pelajar yang lebih baik sehingga dapat mencapai hasil yang diingini.

Selain itu, MIT akan memberi kesempatan kepada guru untuk

12PPK, Aplikasi Teori Kecerdasan Pelbagai dalam Pengajaran dan Pembelajaran (Kuala Lumpur: Kementrian Pendidikan Malaysia, 2001), 143. mendalami aspek penilaian yang lebih efektif. Kecerdasan yang berbeda-beda akan menghasilkan penilaian yang mantap tarhadap kemampuan siswa dalam sesuatu bidang. Teori kecerdasan berbagai juga secara tidak langsung mendukung pembelajaran terpadu dan menyaluruh yang sejalan dengan filosofi pendidikan nasional.

Jadi, MIT merupakan suatu teori kecerdasan yang memandang setiap individu mempunyai beberapa potensi kecerdasan dengan tingkat kognitif yang berbeda-beda yang harus dikembangkan guna untuk pendekatan pembelajaran. Setiap individu sekurang-kurangnya memiliki delapan kecerdasan yang harus dikembangkan. Dari delapan kecerdasan tersebut dapat disimpulkan bahwa setiap kecerdasan bekerja dalam sistem otak yang relatif tersendiri namun pada saat mengeluarkannya, delapan jenis kecerdasan yang ada bekerja sama secara unik untuk menghasilkan informasi sesuai dengan yang dibutuhkan. Dengan kecerdasankecerdasan yang beragam itulah setiap individu mampu untuk menyelesaikan masalah yang terjadi dalam hidup, mampu menyelesaikan persoal-persoal baru untuk dicari solusinya dan mampu menciptakan sesuatu dan memberikan penghargaan bagi seseorang.

Teori kecerdasan majemuk/ berbagai/MIT dianggap dapat menyelesaikan permasalahan pendidikan khususnya di Indonesia. Akan tetapi penerapan dan pengintegrasian MIT 
dalam pembelajaran tidak semudah yang dibayangkan. Chatib menganalisis beberapa tantangan yang harus dihadapi dalam pengaplikasian MIT di dunia pen-didikan Indonesia, yaitu: (1) beberapa elemen sistem pendidikan Indonesia masih kurang sejalan dengan sistem pendidikan yang proporsional; (2) pemahaman yang salah tentang makna sekolah unggulan; (3) desain kurikulum yang masih sentralistis; (4) penerapan kurikulum yang tidak sejalan dengan evaluasi hasil akhir pendidikan; (5) masih rendahnya kreativitas dan kualitas guru; dan (6) proses penilaian hanya dilakukan secara parsial pada kemampuan kognitif yang terbesar, dan belum menggunakan penilaian autentik secara komprehensif.

\section{METODE}

\subsection{Disain}

Penelitian ini merupakan penelitian pengembangan (research and development). ${ }^{13}$ Penelitian ini merupakan penelitian berkelanjutan, pada penelitian pertama yaitu difokuskan pada: (1) analisis kebutuhan, desain dan perancangan; (2) pengembangan model peningkatan kompetensi, validasi dan uji coba serta prototype.

13J. W. Creswell, Educational Research: Planning, Conducting and Evaluating Quantitative dan Qualitative Research (4th ed.) (Boston; Pearson Education, Inc., 2012), 113.

\subsection{Responden}

Penelitian ini ditujukan kepada calon guru pendidikan sekolah dasar/ madrasah ibtidaiyah di dua universitas di Riau, yaitu PGMI FTK UIN Sultan Syarif Kasim Riau dan PGSD FKIP Universitas Riau. Jumlah responden dalam kajian ini adalah total 150 responden yang terdiri dari dua kampus tersebut.

\subsection{Instrumen}

Instrumen penting untuk mencapai objektif sebuah kajian dan bergantung kepada instrumen kajian untuk mengukur sesuatu. Instrumen kajian yang sempurna akan dapat mengukur dengan tepat sesuatu pemboleh ubah dan dapat menjawab persoal yang dikemukakan dengan tepat. Instrumen yang dirancang dalam kajian ini adalah terdiri daripada satu set instrumen lengkap yang dibina berdasarkan konstrukkonstruk yang terdapat dalam keterampilan generik dan teori kecerdasaan berbagai atau Multiple Intellegences Theory (MIT), yang terdiri dari 3 bagian, yaitu bagian A berisikan demografi, mata kuliah pedagogik, dan keterampilan (life skills), sedangkan bagian B berisikan kuistioner angket keterampilan generik dan teori kecerdasaan berbagai/Multiple Intellegences Theory. Selanjutnya, untuk bagian $C$ berisikan soal objektif dan uraian (essay).

\subsection{Analisis Data}

Untuk analis kebutuhan, desain dan perancangan menggunakan analisis dokumen dan analisis profil 
kajian berkaitan keterampilan yang telah dimiliki. Pengembangan instrumen model peningkatan kompetensi, untuk tahap awal akan dijalakan penilaian dari pakar dari korelasi, Pearson, adalah prosedur yang sering digunakan oleh para peneliti untuk mengenal pasti, mengurangkan serta menyusun sebilangan besar item instrumen ke dalam konstruk-konstruk tertentu dibawah satu variabel bersandar dalam sebuah penelitian. ${ }^{14}$ validitas instrumen soal selidik boleh juga dilihat pada nilai korelasi item yang diperbetulkan dengan jumlah skor (corrected item-total correlation) yaitu koefesien korelasi Pearson antara skor bagi setiap item berkaitan dengan jumlah skor tanpa item berkenaan.

Kemudian, validasi dan uji coba dengan menggunakan analisis Kuder Richardson 20 menggunakan Anates V4 dan analisis questioner keterampilan generik dan MIT dengan analisis Alpha Croanbach dengan menggunakan SPSS 22. Hasil analisis data dijadikan dasar dalam pengembangan program pembelajaran berbasis MIT. Penilaian terhadap pengembangan produk buku kerja dilakukan dengan penilaian formatif dan sumatif oleh para ahli dan guru serta mahasiswa. Hasil analisis dijadikan dasar untuk merevisi prototipe yang dihasilkan (product prototype).

${ }^{14}$ Chua Yan Piaw, Statistik Penyelidikan Lanjutan, Ujian Univariat dan Multivariate (Kuala Lumpur: Mc Graw Hill Education, 2009), 86.

\section{HASIL PEMBINAAN INSTRUMEN}

\subsection{Gambaran Umum Instrumen Penelitian}

Penelitian ini memiliki tujuan untuk menghasilkan sebuah instrumen yang kredibel dan efektif untuk menilai keterampilan generik dan multiple intelensi dari mahasiswa calon guru program studi madrasah ibtidaiyah/ sekolah dasar yang ada di Kota Pekanbaru yaitu di UIN Sultan Syarif Kasim Riau dan Universitas Riau.

Proses pembinaan ini melalui proses yang tersusun rapi dan bertahap guna mendapatkan instrumen yang sesuai tujuan, di mana dalam instrumen yang dirancang dalam kajian ini adalah terdiri daripada satu set instrumen lengkap yang dibina berdasarkan konstruk-konstruk yang terdapat dalam keterampilan generik dan teori kecerdasaan berbagai/Multiple Intellegences Theory (MIT), yang terdiri dari 3 bagian yaitu bagian A berisikan demografi, matakuliah pedagogik, dan keterampilan (life skills), sedangkan bagian B berisikan kuistioner angket keterampilan generik dan teori kecerdasaan berbagai/Multiple Intellegences Theory, selanjutnya, untuk bagian $\mathrm{C}$ berisikan soal objektif dan uraian (essay).

Pada bagian A berisikan Profil responden yang terdiri atas demografi, nilai mata kuliah siswa dan keterampilan (life skills). Pada bagaian A dipilih untuk dapat mengetahui profil responden yang ada dan dapat dilihat dari sisi 
demogerafi yang terdiri dari: jenis kelamin, suku, pembiayaan, universitas dan jenis tempat tinggal. Sedangkan mata kuliah yang dimaksud adalah nilai mata kuliah pedagogik yang berkait rapat dengan keterampilan generik dan calon guru dalam melakukan proses belajar mengajar, yaitu media pembelajaran, strategi belajar mengajar, evaluasi pembelajaran dan pengantar komputer. Selanjutnya untuk keterampilan (life skills) yang dapat dilihat adalah keterampilan dalam berbahasa, keterampilan berkendaraan, keterampilan komputer dan keterampilan kepribadian.

Pada bagian B berisikan kuisteioner/angket yang terdiri atas lima konstruk ketrampilan generik yaitu keterampilan belajar, keterampilan berfikir, keterampilan teknologi, keterampilan menaksir/ menilai dan keterampilan fasilitator dan Sembilan konstruk kecerdasan berbagai atau MIT yang terdiri atas: kecerdasan verbal linguistik, kecerdasan matematika logis, kecerdasan verbal spasial, kecerdasan kinestetik dan jasmani, kecerdasan musikal, kecerdasan interpersonal, kecerdasan intrapersonal, kecerdasan naturalis, kecerdasan eksistensial/ kerohanian.

Pada bagian $\mathrm{C}$ berisikan tentang soal-soal integrasi keterampilan berasaskan kecerdasan berbagai (MIT) yang disajikan dalam bentuk soal objektif dan essay singkat.

\subsection{Validitas dan Realibilitas Instrumen \\ Instrumen yang dibina dianalisis} terlebih dahulu oleh pakar baik itu dosen pakar maupun guru yang berkecimpung di program studi pendidikan madrasah ibtidaiyah/ sekolah dasar. Dalam membina dan menilai instrumen penelitian yang kredibel dan efektif, maka penelitian ini membedah instrumen ini sesuai dengan bahagiannya.

\subsubsection{Profil Responden}

Bagian A hanya perlu disesuaikan dan disepakati dengan pakar sesuai dengan tujuan penelitian untuk mengetahui responden penelitian, di sinilah varibel-variabel yang ingin diketahui dapat dilihat dan digunakan untuk penelitian lebih lanjut.

\subsubsection{Angket/Kuisioner}

Kemudian untuk instrumen bagian B yang berbentuk soal kuistioner/angket dilakukan uji validitas dan realibilitas dengan menggunakan software SPSS 22 sedangkan untuk bagain $C$ yang berbentuk soal objektif dan essay digunakan software Anates.

Dalam penelitian ini, instrumen yang disebarkan adalah 200 buah, di mana dalam proses pensortiran dan pemilihan instrumen yang baik dan benar maka, hanya instrumen yang terisikan lengkap saja yang diperoleh dan disesuaikan dengan proposal, yaitu sebanyak 150 sampel kajian yang di analisis. 
Bagi instrumen bagian A, pengkaji telah mendapatkan persetujuan dari tim penelitian dan juga validitas dari pakar didapati bahwa dalam profil responden ini terdiri atas demografi (jenis kelamin, suku, pembiayaan, universitas dan jenis tempat tinggal), mata kuliah pedagogik (media pembelajaran, strategi belajar mengajar, evaluasi pembelajaran dan pengantar komputer), keterampilan/life skills (keterampilan dalam berbahasa, keterampilan berkendaraan, keterampilan komputer dan keterampilan kepribadian).

Kemudian hasil analisis untuk bagian B dalam instrumen ini, daripada analisis yang telah dijalankan, nilai validitas keterampilan generik menggunakan nilai korelasi Pearson bagi setiap konstruk penelitian dan didapati bahwa bagi konstruk keterampilan belajar memiliki nilai korelasi pearson, di atas 0.25 untuk Item 1,3, dan 4 sedangkan item ke 2 dibawah 0.25 untuk itu item yang dapat di gunakan adalah tiga item. Selanjutnya bagi keterampilan berfikir dan fasilitator memiliki nilai korelasi pearson diatas 0.25 untuk item ke 1 , 2 dan 3 sedangkan item ke 4 di bawah 0.25 untuk itu item yang dapat digunakan adalah tiga item. Selanjutnya untuk keterampilan teknologi dan menaksir nilai korelasi Pearson untuk seluruh item diatas 0.25 sehingga keseluruhan item dapat digunakan dalam intrumen ini. Jadi pada soal bagian B untuk angket keterampilan generik terdiri atas 17 soal yang terdiri atas: 3 soal pada setiap konstruk keterampilan belajar, berfikir dan fasilitator dan 4 soal pada setiap konstruk keterampilan teknologi dan menaksir.

Kemudian, bagi nilai validitas kecerdasan berbagai (MIT) menggunakan nilai korelasi Pearson bagi setiap konstruk penelitian dan didapati bahwa bagi konstruk kecerdasan verbal linguistik, Spasial memiliki nilai korelasi Pearson di atas 0.25 untuk item 1,2, dan 3 sedangkan item ke 4 di bawah 0.25 untuk itu item yang dapat di gunakan adalah tiga item. Selanjutnya, bagi kosntruk kecerdasan kecerdasan verbal logis, kinestetik jasmani, musikal dan interpersonal memiliki nilai korelasi Pearson untuk seluruh item di atas 0.25. sehingga keseluruhan item dapat digunakan dalam intrumen ini. Sedangkan bagi konstruk kecerdasan intrapersonal, naturalis dan kerohanian memiliki nilai korelasi Pearson tersebut 0.25 untuk item 2,3, dan 4 sedangkan item ke 1 di bawah 0.25 . Untuk itu item yang dapat digunakan adalah tiga item). Jadi pada soal angket untuk kecerdasan berbagai (MIT) terdiri atas 31 soal yang terdiri atas 3 soal untuk setiap konstrak kecerdasan verbal linguistik, spasial, intrapersonal, naturalis dan kerohanian, dan 4 soal untuk setiap konstruk kecerdasan matematika logis, kinestetik-jasmani, musikal, dan interpersonal.

Kemudian hasil dari analisis Validitas dengan menggunakan analisis pearson digunakan dan selanjutnya data dikomputerkan lalu 
diteruskan untuk melihat realibilitas instrumen daripada data penelitian adalah seperti yang ditunjukkan dalam tabel 1.

Nilai korelasi item dengan jumlah skor yang diperbetulkan dan indeks realibilitas croanbach alpha bagi setiap konstruk keterampilan generik dalam penelitian ini didapati bahwa nilai keseluruhan yang diperoleh dari konstruk keterampilan belajar, keterampilan berfikir, keterampilan tekhnologi, keterampilan menaksir dan keterampilan fasilitator adalah di atas 0.6, dengan masing-masing nilai croanbach alpha adalah 0.76, 0.76, 0.83, 0.84, dan 0.79.

Berdasarkan kepada pandangan Mohd. Majid, ${ }^{15}$ instrumen kajian ini mempunyai indeks nilai realibilitas yang baik dan dapat menjadi instrumen yang kridibel dan efektif. Manakala jika dilihat dari nilai korelasi item dengan jumlah skor yang diperbetulkan (corrected item-total correlation) untuk semua konstruk dalam instrumen kajian, didapati nilai korelasi adalah melebihi 0.30. Menurut Nunally, jika nilai korelasi item dengan jumlah skor yang diperbetulkan (corrected item-total correlation) melebihi 0.25 , maka itemitem tersebut mempunyai validitas yang tinggi dan boleh digunakan untuk mengukur konstruk yang terlibat dalam penelitian.

Nilai korelasi item dengan jumlah skor yang diperbetulkan dan indeks realibilitas croanbach alpha bagi

15Mohd. Majid Konting, Kaedah Penyelidikan Pendidikan (Kuala Lumpur: Dewan Bahasa dan Pustaka, 1990), 112. setiap konstruk kecerdasan berbagai (MIT) dalam penelitian ini, sebagaimana terdapat dalam tabel 2, didapati bahwa nilai croanbach alpha keseluruhan yang diperoleh dari konstruk kecerdasan verbal linguistik, kecerdasan matematika logis, kecerdasan verbal spasial, kecerdasan kinetik jasmani, kecerdasan musikal, kecerdasan interpersonal, kecerdasan intrapersonal, kecerdasan naturalis dan kecerdasan kerohanian (eksistensial) adalah diatas 0.6 dengan masingmasing nilai adalah $0.79,0.83,0.88$, $0.82,0.85,0.85,0.79,0.89$ dan 0.86 .

Berdasarkan kepada pandangan Mohd. Majid, ${ }^{16}$ instrumen kajian ini mempunyai indeks realibilitas yang baik dan dapat menjadi instrumen yang kridibel dan efektif. Manakala jika dilihat dari nilai korelasi item dengan jumlah skor yang diperbetulkan (corrected item-total correlation) untuk semua konstruk dalam instrumen kajian, didapati nilai korelasi intrumen kecerdasan berbagai (MIT) adalah melebihi 0.30 . Menurut Nunally, jika nilai korelasi item dengan jumlah skor yang diperbetulkan (corrected item-total correlation) melebihi 0.25 , maka itemitem tersebut mempunyai validitas yang tinggi dan boleh digunakan untuk mengukur konstruk yang terlibat dalam penelitian.

Penulis menegaskan bahwa instrumen kuisioner/angket keterampilan generik dan kecerdasan berbagai (MIT) telah terbukti memiliki validitas dan realibilitas

16Ibid., 113. 
yang tinggi dan ini menjadikan instrumen pembinaan ini menjadi kridibel dan efesien bagi melihat keterampilan generik dan kecerdasan berbagai (MIT) daripada calon guru.

\subsubsection{Soal Kompetensi Objektif dan Essay Singkat}

Untuk bagian C ini dalam instrumen yang dibangunkan maka peneliti ingin merancang soal intrumen dengan bentuk soal pertanyaan objektif dan essay singkat. Untuk melihat validitas dan realibilitas soal dalam bentuk objektif dan juga uraian singkat (essay singkat) dapat dinilai dengan menggunakan analisis Kuder Richardson 20 (KR20) dengan menggunakan software Anates 4 instrumen awal yang dibangun soal objektif dan essay yang mewakili teori kecerdasan berbagai (MIT).

Peneliti telah menentukan nilai indeks diskriminan dan indeks kesukaran serta nilai realibilitas dengan menggunakan Anates 4 yang didapati bahwa nilai realibilitas Kuder Richardson 20 sebesar 0,73 bagi soal objektif dan 0.78 bagi soal uraian/essay singkat. Hasil analisis indeks diskriminan dan indeks kesukaran serta nilai realibilitas ujian integrasi keterampilan dengan kecerdasan berbagai (MIT) seperti pada tabel 3.

Diketahui bahwa nilai realibilitas Kuder Richardson 20 sebesar 0.73 menunjukkan bahwa soal objektif yang terintegrasi keterampilan berasaskan kecerdasan berbagai $(M I T)$ telah memiliki indeks realibilitas untuk melakukan penelitian yang kredibel dan efektif. Jadi, total soal objektif yang digunakan dalam instrumen adalah sebanyak 18 soal yang terdiri atas sembilan sub konstruk yang telah ditentukan dalam penelitian ini.

Kemudian untuk soal uraian singkat/essay singkat pula dijalankan untuk melihat realibilitasnya. Dan didapati bahwa realibilitas Kuder Richardson 20 (KR20) untuk soal urian essay singkat adalah sebesar 0.78 seperti pada tabel 4.

Diketahui bahwa nilai realibilitas Kuder Richardson 20 bagi soal uraian/essay singkat sebesar 0.78 menunjukkan bahwa soal uraian/ essay singkat yang terintegrasi keterampilan berasaskan kecerdasan berbagai (MIT) telah memiliki indeks realibilitas untuk melakukan penelitian yang kredibel dan efektif. Jadi, total soal essay yang digunakan dalam instrumen adalah sebanyak 10 soal.

\section{KESIMPULAN}

Berdasarkan hasil penelitian ini, dapat disimpulkan bahwa perlunya peningkatan kompetensi dan daya saing lulusan calon guru PGMI/PGSD agar pembelajaran di kelas dapat berjalan dengan efektif dan efisien. Dari pembinaan dan pembangunan instrumen yang telah dijalankan diketahui bahwa satu set instrumen lengkap yang dibina berdasarkan konstruk-konstruk yang terdapat dalam keterampilan generik dan teori kecerdasaan berbagai/ 
Multiple intellegences theory (MIT), yang terdiri dari 3 bagian yaitu bagian A berisikan demografi, mata kuliah pedagogik, dan keterampilan (life skills), sedangkan bagian B berisikan kuisioner angket keterampilan generik dan teori kecerdasaan berbagai/Multiple intellegences theory, selanjutnya, untuk bagian $\mathrm{C}$ berisikan soal objektif dan uraian (essay).

Dari hasil penelitian, diketahui bahwa nilai croanbach alpha setiap konstruk keterampilan generik dari konstruk keterampilan belajar, keterampilan berfikir, keterampilan tekhnologi, keterampilan menaksir dan keterampilan fasilitator adalah diatas 0.6 dengan masing-masing nilai croanbach alpha adalah $0.76,0.76$, 0.83, 0.84, dan 0.79. dan untuk setiap konstruk kecerdasan berbagai (MIT) dalam penelitian ini didapati bahwa nilai croanbach alpha keseluruhan yang diperoleh dari konstruk kecerdasan verbal linguistik (0.79), kecerdasan matematik logis (0.83), kecerdasan verbal spasial (0.88), kecerdasan kinetik jasmani (0.82), kecerdasan musikal (0.85), kecerdasan interpersonal (0.85), kecerdasan intrapersonal (0.79), kecerdasan naturalis (0.89) dan kecerdasan kerohanian (eksistensial) (0.89). Manakala bagi soal objektif nilai realibilitas Kuder Richardson 20 sebesar 0.73 dan untuk soal urian essay singkat adalah sebesar 0.78 . Sehingga dapat disimpulkan bahwa instrumen yang telah dibina dan dikembangkan oleh peneliti telah memiliki validitas dan realibilitas yang baik, ini bermakna bahwa instrumen ini sangant kredibel dan efektif dalam meningkatkan keterampilan generik dan kecerdasan berbagai (MIT) pada diri calon guru.

Untuk penelitian selanjutnya akan dikembangkan lebih lengkap lagi, tidak hanya untuk mahasiswa yang akan dipersiapkan menjadi guru tetapi juga buku guru dalam meningkatkan kompetensi dan kualitas, serta profesionalisme yang berbasis kecerdasan berbagai (MIT). Dengan meningkatnya kompetensi dan penguasaan konsep yang baik akan menghasilkan peserta didik yang berkualitas dan mengangkat kemajuan dan perkembangan bangsa dan negara "better teacher, better future."

\section{REFERENSI}

[1] Armstrong, T., Multiple intelligences in the classroom (3nd ed.). Alexandria, VA: ASCD., 2009)

[2] Creswell, J. W. Educational Research: Planning, Conducting and Evaluating Quantitative dan Qualitative Research. (4th ed.). Boston; Pearson Education, Inc., 2012.

[3] Gardner, Howard, Multiple Intelligences: The Theory in Practice. New York: Basic Books, 1993.

[4] Gonzales, P., Williams, T., Jocelyn, L., Roey, S., Kastberg, D., and Brenwald, S. Highlights From TIMSS 2007: Mathematics and Science Achievement of U.S. Fourth-and Eighth-Grade Students 
in an International Context (NCES 2009-001). Washington DC.: National Center for Education Statistics, Institute of Educationn Sciences, U.S. Department of Education, 2008.

[5] Herrington, J. et. al. "Designbased research and doctoral students: Guidelines for preparing adissertation proposal." In Montgomerie, C. \& Seale, J. (Eds.). Proceedings of World Conference on Educational Multimedia, Hypermedia and Telecommunications. 2007: 40894097.

[6] Hidayat, Bahrul \& Yusuf, Suhendra. Benchmark Internasional Mutu Pendidikan. Jakarta: Bumi Aksara, 2010.

[7] Konting, Mohd. Majid. Kaedah Penyelidikan Pendidikan. Kuala Lumpur: Dewan Bahasa dan Pustaka, 1990.

[8] Piaw, Chua Yan. Statistik Penyelidikan Lanjutan, Ujian Univariat dan Multivariate. Kuala Lumpur: Mc Graw Hill Education, 2009

[9] PPK. Aplikasi Teori Kecerdasan Pelbagai dalam Pengajaran dan Pembelajaran. Kuala Lumpur: Kementrian Pendidikan Malaysia, 2001.

[10] Suryawati, Evi. "Pengembangan Model Peningkatan Kompetensi dan Daya Saing Lulusan MIPA LPTK Berbasis KKNI dan Kerangka TPCK." Stranas. 2015

[11] Tan, O.S. Problem-Based Learning Innovation:Using Problem to Power Learning in the 21st Century. Singapore: GALE Cengage Learning, 2004.

[12] Vebrianto, R., \& Osman, K. "The effect of multiple media instruction in improving students' science process skill and achievement." Procedia Social and Behavioral Sciences 15 (2011): 346-350
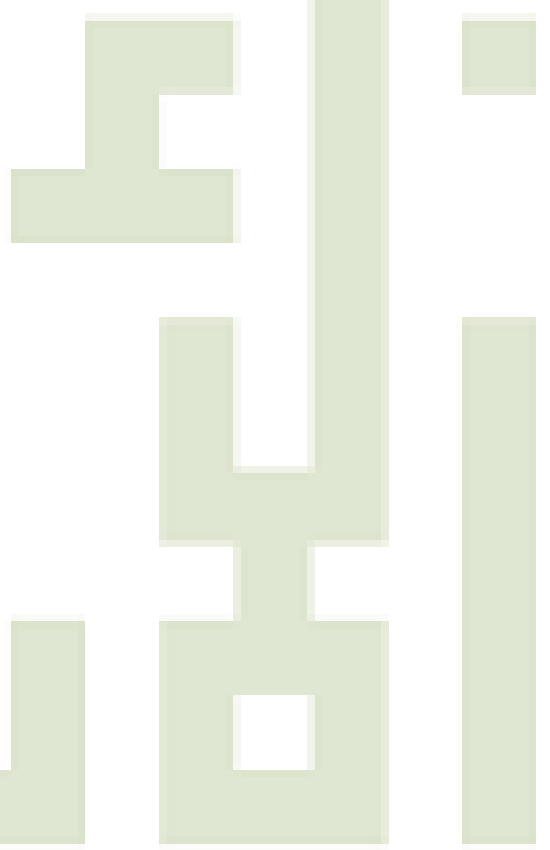
Tabel 1. Validitas instrumen menggunakan nilai korelasi item dengan jumlah skor yang diperbetulkan dan indeks Cronbach Alpha bagi setiap konstruk keterampilan generik

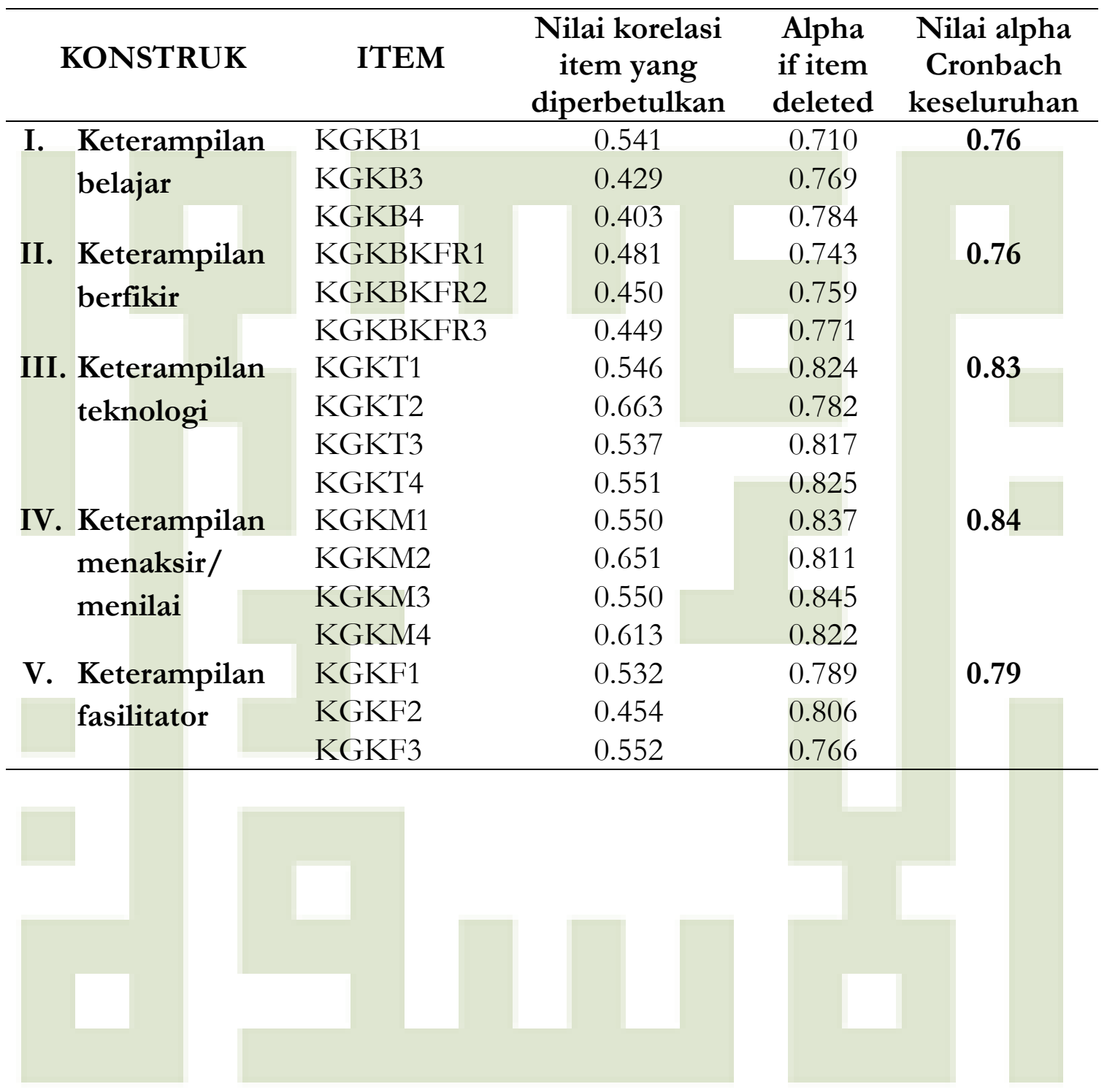


Tabel 2. Validitas instrumen menggunakan nilai korelasi item dengan jumlah skor yang diperbetulkan dan indeks realibilitas Cronbach Alpha bagi setiap konstruk kecerdasan berbagai (MIT)

\begin{tabular}{|c|c|c|c|c|}
\hline KONSTRUK & ITEM & $\begin{array}{l}\text { Nilai korelasi } \\
\text { Item yang } \\
\text { diperbetulkan }\end{array}$ & $\begin{array}{l}\text { Alpha if } \\
\text { item } \\
\text { deleted }\end{array}$ & $\begin{array}{l}\text { Nilai alpha } \\
\text { Cronbach } \\
\text { keseluruhan }\end{array}$ \\
\hline \multirow{3}{*}{$\begin{array}{ll}\text { I. } & \text { Kecerdasan } \\
\text { verbal linguistic }\end{array}$} & Linguistik1 & 0.518 & 0.780 & \multirow[t]{3}{*}{0.79} \\
\hline & Linguistik2 & 0.501 & 0.780 & \\
\hline & Linguistik3 & 0.509 & 0.796 & \\
\hline \multirow{4}{*}{$\begin{array}{l}\text { II. Kecerdasan } \\
\text { matematik- } \\
\text { logis }\end{array}$} & Logis1 & 0.674 & 0.778 & \multirow[t]{4}{*}{0.83} \\
\hline & Logis2 & 0.633 & 0.786 & \\
\hline & Logis3 & 0.504 & 0.820 & \\
\hline & Logis4 & 0.436 & 0.843 & \\
\hline \multirow{3}{*}{$\begin{array}{l}\text { III. Kecerdasan } \\
\text { verbal-spasial }\end{array}$} & Spasial1 & 0.546 & 0.824 & \multirow[t]{3}{*}{0.88} \\
\hline & Spasial2 & 0.663 & 0.782 & \\
\hline & Spasial3 & 0.537 & 0.817 & \\
\hline \multirow{4}{*}{$\begin{array}{l}\text { IV. Kecerdasan } \\
\text { kinestetik- } \\
\text { jasmani }\end{array}$} & Jasmani1 & 0.566 & 0.798 & \multirow[t]{4}{*}{0.82} \\
\hline & Jasmani2 & 0.656 & 0.771 & \\
\hline & Jasmani3 & 0.487 & 0.832 & \\
\hline & Jasmani4 & 0.502 & 0.814 & \\
\hline \multirow{4}{*}{$\begin{array}{l}\text { V. Kecerdasan } \\
\text { musikal }\end{array}$} & Musikal1 & 0.532 & 0.856 & \multirow[t]{3}{*}{0.85} \\
\hline & Musikal2 & 0.680 & 0.820 & \\
\hline & Musikal3 & 0.665 & 0.824 & \\
\hline & Musikal4 & 0.563 & 0.856 & \multirow{5}{*}{0.85} \\
\hline \multirow{4}{*}{$\begin{array}{l}\text { VI. Kecerdasan } \\
\text { interpersonal }\end{array}$} & Interpersonal1 & 0.498 & 0.878 & \\
\hline & Interpersonal2 & 0.643 & 0.821 & \\
\hline & Interpersonal3 & 0.637 & 0.823 & \\
\hline & Interpersonal4 & 0.659 & 0.817 & \\
\hline VII. Kecerdasan & Intrapersonal2 & 0.517 & 0.813 & \multirow[t]{3}{*}{0.79} \\
\hline intrapersonal & Intrapersonal3 & 0.575 & 0.755 & \\
\hline & Intrapersonal4 & 0.477 & 0.801 & \\
\hline \multirow{3}{*}{$\begin{array}{l}\text { VIII. Kecerdasan } \\
\text { naturalis }\end{array}$} & Naturalis2 & 0.675 & 0.884 & \multirow[t]{2}{*}{0.89} \\
\hline & Naturalis3 & 0.728 & 0.885 & \\
\hline & Naturalis4 & 0.704 & 0.774 & \multirow{4}{*}{0.86} \\
\hline \multirow{3}{*}{$\begin{array}{r}\text { IX. Kecerdasan } \\
\text { eksistensial } \\
\text { kerohanian }\end{array}$} & Eksistensial2 & 0.683 & 0.826 & \\
\hline & Eksistensial3 & 0.729 & 0.808 & \\
\hline & Eksistensial4 & 0.500 & 0.918 & \\
\hline
\end{tabular}


Tabel 3. Nilai Indeks diskriminan dan indeks kesukaran serta nilai realibilitas soal objektif integrasi ketrampilan dengan kecerdasan berbagai (MIT)

\begin{tabular}{cccccc}
\hline No. Soal & $\begin{array}{c}\text { ID } \\
\mathbf{( \% )}\end{array}$ & $\begin{array}{c}\text { IK } \\
\mathbf{( \% )}\end{array}$ & $\begin{array}{c}\text { Interpretasi } \\
(\mathbf{I K})\end{array}$ & $\begin{array}{c}\text { Tahap } \\
\text { penerimaan }\end{array}$ & $\begin{array}{c}\text { Kuder } \\
\text { Richardson 20 }\end{array}$ \\
\hline 1 & 70.00 & 55.26 & Sedang & Diterima & 0.73 \\
2 & 40.00 & 60.53 & Sedang & Diterima & \\
3 & 90.00 & 50.00 & Sedang & Diterima & \\
4 & 70.00 & 63.16 & Sedang & Diterima & \\
5 & 50.00 & 63.16 & Sedang & Diterima & \\
6 & 60.00 & 68.42 & Sedang & Diterima & \\
7 & 20.00 & 42.11 & Sedang & Diterima & \\
8 & 60.00 & 65.79 & Sedang & Diterima & \\
9 & 70.00 & 39.47 & Sedang & Diterima & \\
10 & 60.00 & 34.21 & Sedang & Diterima & \\
11 & 70.00 & 55.26 & Sedang & Diterima & \\
12 & 50.00 & 52.63 & Sedang & Diterima & \\
13 & 80.00 & 47.37 & Sedang & Diterima & \\
14 & 70.00 & 52.63 & Sedang & Diterima & \\
15 & 50.00 & 26.32 & Sukar & Diterima & \\
16 & 20.00 & 28.95 & Sukar & Diterima & \\
17 & 70.00 & 76.32 & Sedang & Diterima & \\
18 & 30.00 & 47.37 & Sedang & Diterima & \\
\hline
\end{tabular}

Tabel 4. Nilai indeks diskriminan dan indeks kesukaran serta nilai realibilitas solan uraian/essay singkat integrasi keterampilan dengan kecerdasan berbagai (MIT)

\begin{tabular}{cccccc}
\hline No Soal & $\begin{array}{c}\text { ID } \\
\mathbf{( \% )}\end{array}$ & $\begin{array}{c}\text { IK } \\
\mathbf{( \% )}\end{array}$ & Interpretasi & $\begin{array}{c}\text { Tahap } \\
\text { penerimaan }\end{array}$ & $\begin{array}{c}\text { Kuder } \\
\text { Richardson 20 }\end{array}$ \\
\hline 1 & 27.50 & 33.75 & Sedang & Diterima & 0.78 \\
2 & 27.50 & 33.75 & Sedang & Diterima & \\
3 & 20.00 & 48.75 & Sedang & Diterima & \\
4 & 15.00 & 33.75 & Sedang & Diterima & \\
5 & 10.00 & 28.75 & Sukar & Diterima & \\
6 & 17.50 & 37.50 & Sedang & Diterima & \\
7 & 18.75 & 35.63 & Sedang & Diterima & \\
8 & 13.75 & 30.63 & Sedang & Diterima & \\
9 & 21.25 & 45.63 & Sedang & Diterima & \\
10 & 20.00 & 36.25 & Sedang & Diterima & \\
\hline
\end{tabular}

